\title{
Variable penetrance of Andersen-Tawil syndrome in a family with a rare missense KCNJ2 mutation
}

Reem Deeb, MD, Aravindhan Veerapandiyan, MBBS, Rabi Tawil, MD, and Simona Treidler, MD

Neurol Genet 2018;4:e284. doi:10.1212/NXG.0000000000000284

\author{
Correspondence \\ Dr. Tawil \\ Rabi_Tawil@urmc.rochester.edu
}

Andersen-Tawil syndrome is an autosomal dominant potassium channelopathy characterized by episodic flaccid muscle weakness (periodic paralysis), cardiac abnormalities (ventricular arrhythmias, prolonged $\mathrm{QT}$ interval, and prominent $\mathrm{U}$ waves), and characteristic skeletal features (low set ears, ocular hypertelorism, small mandible, fifth digit clinodactyly, syndactyly, short stature, scoliosis, and broad forehead). ${ }^{1}$ Mutations in the KCNJ2 gene on chromosome 17 q23 are found in about $60 \%$ of the patients with Andersen-Tawil syndrome. ${ }^{2}$ In the absence of a genetic change in KCNJ2, diagnosis of Andersen-Tawil syndrome is established by the presence of well-defined clinical findings. The distinctive clinical triad of Andersen-Tawil syndrome is present in $60 \%-80 \%$ of patients with KCNJ2 mutations. ${ }^{1,2}$ KCNJ2 encodes the pore-forming subunit of an inward-rectifying potassium channel protein, Kir2.1, helping in skeletal and cardiac muscle resting membrane potential stabilization. Mutations in this gene cause loss of function and dominant-negative suppression effects on the Kir2.1 protein, leading to disruption of the cardiac and skeletal muscle excitability. ${ }^{2,3}$ KCNJ2 mutations in AndersenTawil syndrome affect multiple tissues and results in a wide phenotypic variability causing diagnostic difficulties and delay. ${ }^{2}$ We describe the varied clinical characteristics of AndersenTawil syndrome in a Caucasian family (mother and her 2 daughters) with a rare missense mutation in KCNJ2.

The 42-year-old mother presented with a 15-year history of episodes of periodic paralysis affecting her upper or lower extremities. In the absence of a clear diagnosis, she was treated with systemic steroids on multiple occasions for presumed polymyositis. At the age of 34 years, during the first trimester of her first pregnancy, she had an episode of paralysis associated with hypokalemia. The weakness recovered after potassium supplementation. Her 7-year-old daughter has episodic muscle weakness, cardiac involvement with premature ventricular contractions and prominent $U$ wave, and distinctive skeletal features while the younger daughter has only skeletal features. Both daughters had normal birth and development. The clinical features of our patients are described in the figure. Targeted sequencing of the KCNJ2 gene showed a heterozygous missense mutation (c. $575 \mathrm{C}>\mathrm{T}$; p.Thr192Ile) in exon 2 in the mother and both daughters. The testing was based on identification of the same mutation in mother's 21-year-old niece who was noted to have prolonged QT interval during an evaluation for syncope. She also has short toes and syndactyly, but no reported episodic weakness. The mother's brother, an obligate carrier, is asymptomatic.

The missense mutation of p.Thr192Ile found in our patients was previously reported in a single Taiwanese family with Andersen-Tawil syndrome. ${ }^{4}$ The proband was a 35-year-old woman with typical clinical triad of Andersen-Tawil syndrome and fixed extremity and truncal weakness. In addition, she was also noted to have pyramidal tract signs and major

From the Department of Neurology (R.D.), SUNY Downstate Medical Center, Brooklyn; Department of Neurology (A.V., R.T.), University of Rochester Medical Center; and Department of Neurology (S.T.), Stony Brook School of Medicine, NY.

Funding information and disclosures are provided at the end of the article. Full disclosure form information provided by the authors is available with the full text of this article at Neurology.org/NG.

The Article Processing Charge was funded by the authors.

This is an open access article distributed under the terms of the Creative Commons Attribution-NonCommercial-NoDerivatives License 4.0 (CC BY-NC-ND), which permits downloading and sharing the work provided it is properly cited. The work cannot be changed in any way or used commercially without permission from the journal. 
Figure Clinical features and pedigree of patients

\begin{tabular}{|c|c|c|c|}
\hline Clinical features & Mother & Daughter 1 & Daughter 2 \\
\hline Age (years) & 42 & 7 & 5 \\
\hline Periodic paralysis & Yes & Yes & No \\
\hline $\begin{array}{l}\text { Fixed muscle } \\
\text { weakness }\end{array}$ & $\begin{array}{l}\text { Mild proximal } \\
\text { weakness }\end{array}$ & No & No \\
\hline Cardiac abnormalities & None & $\begin{array}{l}\text { Prominent U waves, } \\
\text { premature } \\
\text { ventricular } \\
\text { contractions }\end{array}$ & None \\
\hline Skeletal features & $\begin{array}{l}\text { Short stature, small } \\
\text { chin, low set ears, } \\
\text { hypertelorism, } \\
\text { clinodactyly }\end{array}$ & $\begin{array}{l}\text { Short stature, small } \\
\text { chin, low set ears, } \\
\text { clinodactyly, } \\
\text { syndactyly }\end{array}$ & $\begin{array}{l}\text { Short stature, small } \\
\text { chin, low set ears, } \\
\text { clinodactyly, } \\
\text { syndactyly }\end{array}$ \\
\hline Ictal serum potassium & Low & Normal & Not applicable \\
\hline Treatment & $\begin{array}{l}\text { Low dose potassium, } \\
\text { acetazolamide }^{a}\end{array}$ & None & None \\
\hline
\end{tabular}

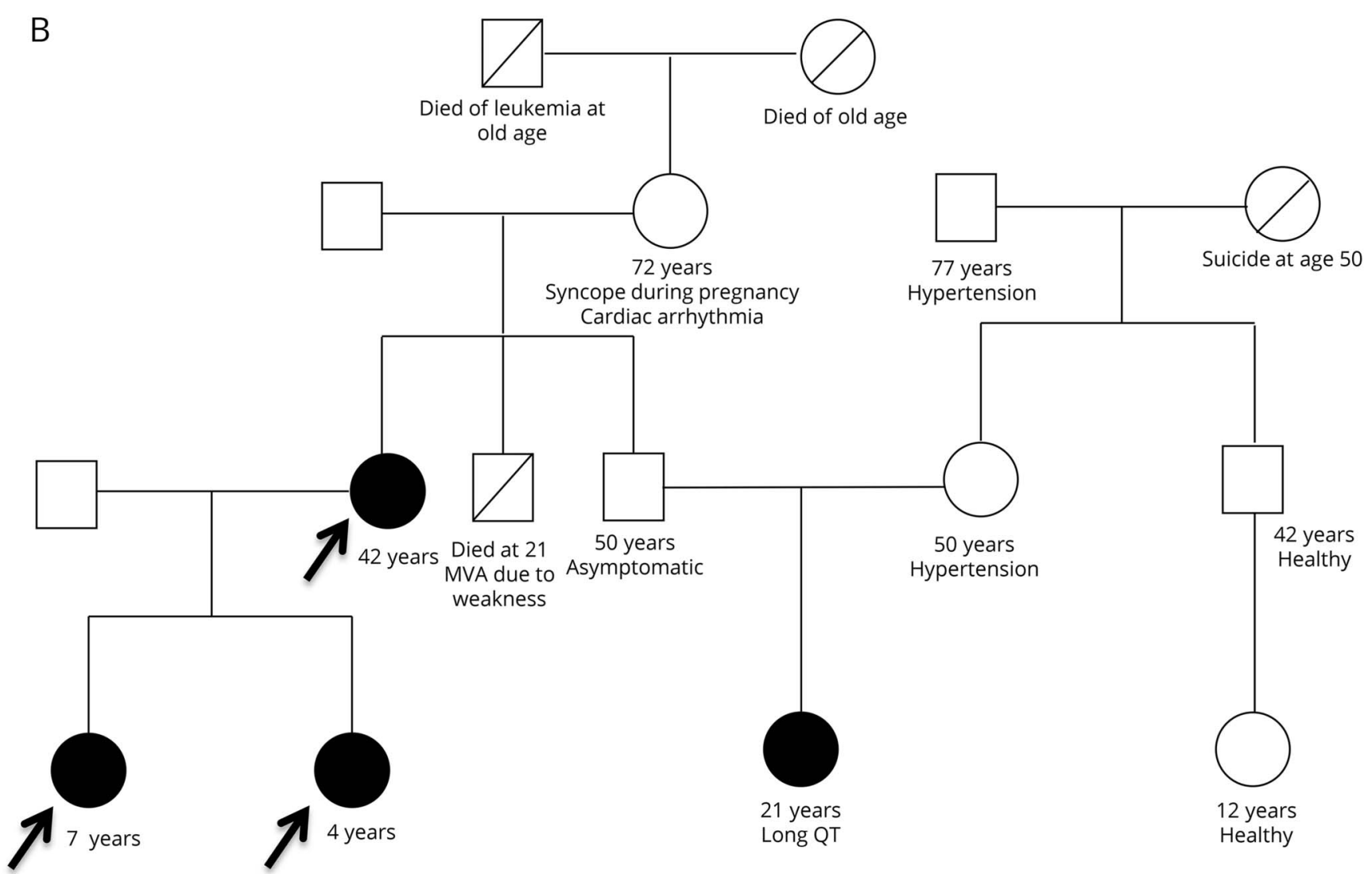

(A) Clinical features of patients. ${ }^{a}$ Low dose extended release potassium due to history of daily muscle weakness; prophylactic acetazolamide in the perimenstrual period as menstruation is a trigger for periodic paralysis in her. (B) Pedigree of patients. Black symbols denote family members affected with Andersen-Tawil syndrome with genetic confirmation. Patients described in this report are indicated by arrows. 
depression. Her 8-year-old son, who was also affected with Andersen-Tawil syndrome with long-QT syndrome and characteristic skeletal features, was identified to have learning disability. Authors of the study postulated that the atypical neuropsychiatric features noted in this family expand the phenotype of Andersen-Tawil syndrome. ${ }^{4}$ Such clinical features (pyramidal tract signs, depression, cognitive delay, and learning disability) were not noted in our patients.

The pathogenicity of the mutation p.Thr192Ile remains unproven in vitro. This missense mutation causes replacement of the amino acid threonine by isoleucine at codon 192 . The amino acid substitution is predicted to be "probably damaging" by the polymorphism phenotyping tool (Polyphen-2). ${ }^{5}$ The p.Thr192 residue is located in the highly conserved region of the C-terminal intracellular domain of the Kir2.1 protein emphasizing its importance during evolution. ${ }^{4-6}$ Moreover, replacement of threonine at this position by another amino acid alanine (p.Thr192Ala) has been reported to be causative for Andersen-Tawil syndrome. ${ }^{6,7}$ We speculate that the heterozygous missense mutation affecting this highly conserved region is associated with the Andersen-Tawil syndrome phenotype in our patients. The kindred described in this report and the kindred that was previously described ${ }^{4}$ provide clinical evidence for pathogenicity of this rare missense mutation in KCNJ2. In addition, our kindred demonstrated the wide intra-familial variability in penetrance of the clinical triad seen in Andersen-Tawil syndrome.

We suggest that physicians should be aware of this rare clinical entity and its high phenotypic variability even within a family while evaluating patients with transient muscle weakness. The subtle clinical and characteristic electrocardiographic features can help with early recognition and treatment.

\section{Study funding}

No targeted funding reported.

\section{Disclosure}

R. Deeb and A. Veerapandiyan report no disclosures. R. Tawil has served on scientific advisory boards for Fulcrum Therapeutics and Acceleron Pharma; serves on the editorial board of the Journal of Neuromuscular Diseases; receives publishing royalties from Wiley-Blackwell; has been a consultant for Acceleron; and has received research support from Fulcrum Therapeutics, NIH, and the FSH Society. S. Treidler reports no disclosures. Full disclosure form information provided by the authors is available with the full text of this article at Neurology.org/NG.

Received July 10, 2018. Accepted in final form September 25, 2018.

\section{References}

1. Veerapandiyan A, Statland JM, Tawil R. Andersen-tawil syndrome. In: Adam MP, Ardinger HH, Pagon RA, et al, editors. GeneReviews ${ }^{\circ}$. Seattle, WA: University of Washington; 1993.

2. Statland JM, Fontaine B, Hanna MG, et al. Review of the diagnosis and treatment of periodic paralysis. Muscle Nerve 2018;57:522-530.

3. Plaster NM, Tawil R, Tristani-Firouzi M, et al. Mutations in Kir2.1 cause the developmental and episodic electrical phenotypes of Andersen's syndrome. Cell 2001;105:511-519.

4. Chan HF, Chen ML, Su JJ, Ko LC, Lin CH, Wu RM. A novel neuropsychiatric phenotype of KCNJ2 mutation in one Taiwanese family with Andersen-Tawil syndrome. J Hum Genet 2010;55:186-188.

5. Adzhubei IA, Schmidt S, Peshkin L, et al. A method and server for predicting damaging missense mutations. Nat Methods 2010;7:248-249.

6. Haruna Y, Kobori A, Makiyama T, et al. Genotype-phenotype correlations of KCNJ2 mutations in Japanese patients with Andersen-Tawil syndrome. Hum Mutat 2007;28:208.

7. Soom M, Schonherr R, Kubo Y, Kirsch C, Klinger R, Heinemann SH. Multiple PIP2 binding sites in Kir2.1 inwardly rectifying potassium channels. FEBS Lett 2001;490: $49-53$.

Appendix 1 Author contributions

\begin{tabular}{llll}
\hline Name & Location & Role & Contribution \\
\hline Reem Deeb, MD & SUNY Downstate Medical Center, New York & Author & Drafting and revising the manuscript \\
\hline $\begin{array}{l}\text { Aravindhan Veerapandiyan, } \\
\text { MBBS }\end{array}$ & University of Rochester Medical Center, New York & Author & Study concept and revising the manuscript \\
\hline Rabi Tawil, MD & University of Rochester Medical Center, New York & Author & Study concept and revising the manuscript \\
\hline Simona Treidler, MD & Stony Brook School of Medicine, New York & Author & Study concept, drafting, and revising the manuscript
\end{tabular}




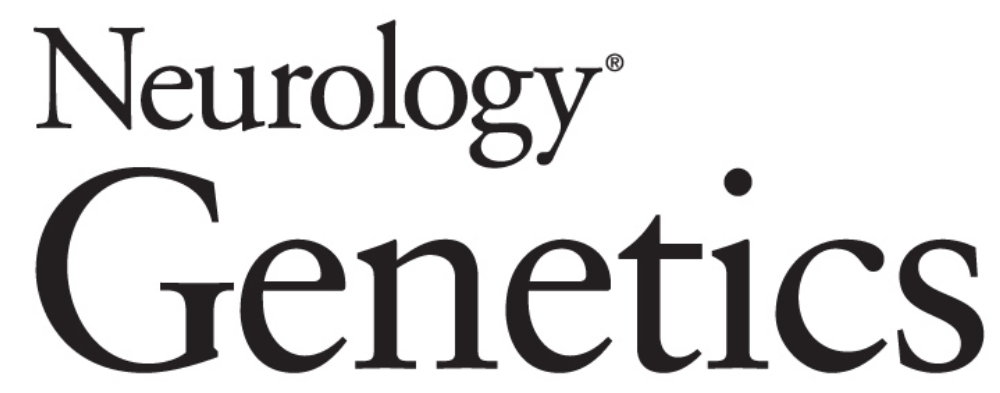

Variable penetrance of Andersen-Tawil syndrome in a family with a rare missense KCNJ2 mutation

Reem Deeb, Aravindhan Veerapandiyan, Rabi Tawil, et al. Neurol Genet 2018;4;

DOI 10.1212/NXG.0000000000000284

This information is current as of October 25, 2018

Neurol Genet is an official journal of the American Academy of Neurology. Published since April 2015, it is an open-access, online-only, continuous publication journal. Copyright Copyright @ 2018 The Author(s). Published by Wolters Kluwer Health, Inc. on behalf of the American Academy of Neurology.. All rights reserved. Online ISSN: 2376-7839.

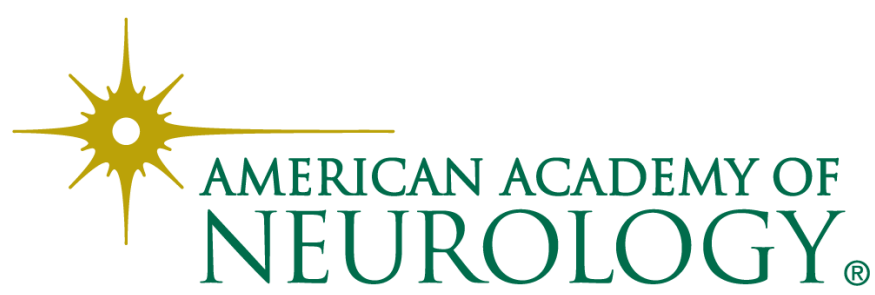




\section{Updated Information \& Services}

\section{References}

Citations

Subspecialty Collections

Permissions \& Licensing

\section{Reprints}

including high resolution figures, can be found at: http://ng.neurology.org/content/4/6/e284.full.html

This article cites 6 articles, 0 of which you can access for free at: http://ng.neurology.org/content/4/6/e284.full.html\#\#ref-list-1

This article has been cited by 1 HighWire-hosted articles: http://ng.neurology.org/content/4/6/e284.full.html\#\#otherarticles

This article, along with others on similar topics, appears in the following collection(s):

\section{All Genetics}

http://ng.neurology.org//cgi/collection/all_genetics

All Pediatric

http://ng.neurology.org//cgi/collection/all_pediatric

Muscle disease

http://ng.neurology.org//cgi/collection/muscle_disease

Information about reproducing this article in parts (figures,tables) or in its entirety can be found online at:

http://ng.neurology.org/misc/about.xhtml\#permissions

Information about ordering reprints can be found online:

http://ng.neurology.org/misc/addir.xhtml\#reprintsus

Neurol Genet is an official journal of the American Academy of Neurology. Published since April 2015, it is an open-access, online-only, continuous publication journal. Copyright Copyright $\odot 2018$ The Author(s). Published by Wolters Kluwer Health, Inc. on behalf of the American Academy of Neurology.. All rights reserved. Online ISSN: 2376-7839.

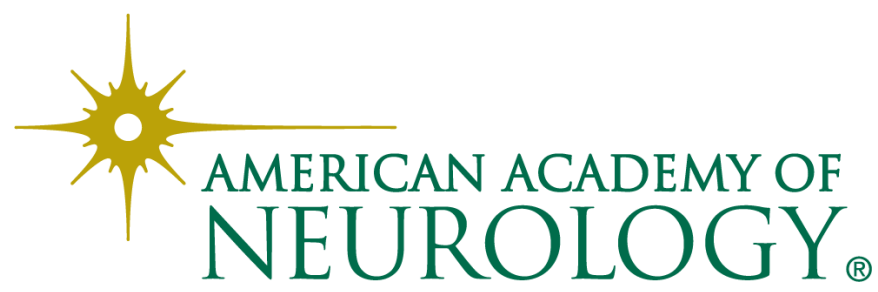

